\title{
An Instrument for Perceiving Ethical Problems in Primary Healthcare: Psychometric Parameters and Ethical Components
}

\author{
Ana Maria de Oliveira1, Valdiney Gouveia ${ }^{2}$, Rui Nunes ${ }^{3}$ \\ ${ }^{1}$ Universidade Federal de Goiás, Goiania, Brazil \\ ${ }^{2}$ Department of Psychology, Federal University of Paraíba, João Pessoa, Brazil \\ ${ }^{3}$ Faculty of Medicine, University of Porto, Porto, Portugal \\ Email: dr.amoliveira@gmail.com, vvgouveia@gmail.com, ruinunes@med.up.pt
}

Received 5 June 2014; revised 4 July 2014; accepted 2 August 2014

Copyright (C) 2014 by authors and Scientific Research Publishing Inc. This work is licensed under the Creative Commons Attribution International License (CC BY). http://creativecommons.org/licenses/by/4.0/

\section{(c) O) Open Access}

\begin{abstract}
Ethical issues in primary (health) care (PC) are common and are confronted daily. In the scarce literature that was available, Zoboli and Silva developed an instrument (IPE-APS) for perceiving ethical conflicts. Two empirical ex post facto studies to gather psychometric evidence for the instrument were outlined. In the first study, 88 nurses and physicians from Brazil's Family Health (Saúde da Família-SF) responded to the IPE-APS, and the results confirmed its validity and accuracy. In total, 14 items were grouped in Factor I (relationship/responsibility), which was described as having human rights and deontological nature (Cronbach's alpha $=0.92$ ), and 11 items were grouped in Factor II, which was described as having a labor structure nature (Cronbach's alpha $=0.90$ ). In the second study, 207 SF professionals in Goiânia, Goiás responded to the IPE-APS. The results showed that Factor I had a high factorial congruence index $(0.98)$, which revealed high similarity and showed that the instrument displayed practical validity to identify and assess ethical problem perception in PC.
\end{abstract}

\section{Keywords}

Bioethics, Psychometrics, Primary Care

\section{Introduction}

Ethical issues in primary care (PC) have recently been studied, in contrast to the studies that have been con-

How to cite this paper: de Oliveira, A.M., Gouveia, V. and Nunes, R. (2014) An Instrument for Perceiving Ethical Problems in Primary Healthcare: Psychometric Parameters and Ethical Components. International Journal of Clinical Medicine, 5, 1020-1029. http://dx.doi.org/10.4236/ijcm.2014.516133 
ducted on dilemmas for the limited conditions at the secondary and tertiary health care levels. Previous authors have hypothesized that little attention is given to ethical issues because of a limited use of technology at the primary care level [1].

Brazilian bioethics includes bioethical themes with a global scope, which are integrated with national information, and emerging themes in public health, globalization, biotechnoscience, research and environment are emphasized [2]-[5]. However, Brazilian bioethics organizations have studied ethical problems to some extent in the Family Health Strategy (Estratégia de Saúde da Família—ESF or PSF), which is the gateway to the Unified Health System (Sistema Único de Saúde-SUS) [1] [6]-[10].

Several instruments have been used for bioethics studies that aim to both test ethical theories (normative ethics) and identify and describe situations (descriptive ethics) that are directly or indirectly implied in value conflicts, such as scales for stress, burnout, attitude, values and behavior [11] [12].

For relationships, ethical conflicts are perceived through four variables: the frequency of occurrence, the level of conflict produced, an individual's exposure to an ethical conflict and the type of ethical conflict [13].

Redman [12] notes that instrument quality for quantifying ethical constructs, such as validity and reliability, is a sine qua non condition for assessing any instrument for quantitation. The author classifies quantitative instruments for bioethics into five categories: professional issues/context, informed consent, life terminability, research and professional confidence.

A systematic study using the LILACS, MEDLINE, Med Carib, PAHO and SciELO databases and the key words "bioethics" and "primary care" in Portuguese, Spanish and English from 2003 to 2012 yielded few publications [1] [7] [11] [14]-[17]. This research gap indicates that the subject lacks more in-depth studies.

Two exceptional Brazilian studies were developed by Zoboli [1] and Silva [8]; the culmination elaborated on the Inventory of Ethical Problems a Primary Health Care (Inventário de Problemas Éticos-Atenção Primária em Saúde-IPE-APS), which was used herein.

To collect psychometric evidence on whether the IPE-APS is an adequate perception and quantification instrument for ethical problems in PC for nurses and doctors, two studies (Study 1 and Study 2) were used to explore the factorial structure of such inventory regarding validity, accuracy and factorial congruence.

\section{Study 1}

This study aimed to collect preliminary evidence for the IPE-APS validity and accuracy; it also aimed to identify, describe and justify the factors underlying instrument given the assumptions in bioethics.

\subsection{Method}

Eighty-eight professionals from the Family Health Units (Unidades Básicas de Saúde da Família—UBSF or USF or UBS) in three municipalities of metropolitan Goiânia (Aparecida de Goiânia, Senador Canedo and Trindade), Brazil participated in the study. Most such professionals were nurses (60.2\%), female (83\%), married (58\%) and Catholic (68\%). This was a convenience sample (non-probabilistic), and the questionnaires were answered spontaneously, which included the following instruments: 1) the IPE-APS, which was adapted from Zoboli and Silva [8] and included 40 items that express situations in the ESF, wherein the subject should answer: a) whether the depicted conditions pose an ethical problem and b), independent from an ethical problem, how often do such conditions arise on a scale from 0 to 3 ( 0 = never; 1 = seldom; 2 = often; and 3 = always); 2 ) sociodemographic data; 3) labor data; and 4) the Table of Social Values (Quadro de Valores Sociais-QVS) with 18 basic values.

Univariate and multivariate quantitative statistical analyses through the PASW (Predictive Analytic Software for Windows) software package, version 18 were used to organize and analyze the data in the database. Many techniques were used, including descriptive statistics, frequency as well as univariate and multivariate analyses, internal consistency or Cronbach's Alpha, principal component analysis and homogeneity.

The project was approved by the Committee for Research Ethics in the Clinics Hospital of the Federal University of Goiás (Comitê de Ética em Pesquisa do Hospital das Clínicas da Universidade Federal de Goiás/UFG) (number 72/2010). Participation among hospital professionals was voluntary, and each participant signed an informed consent form.

\subsection{Results}

Table 1 shows the percentage of answers from the respondent professionals related to each set of conditions and whether such conditions pose an ethical problem. 
Table 1. Potential ethical situation in the ESF for its staff nurses and physicians in the municipalities Aparecida of Goiânia, Senador Canedo and Trindade, Goiás, Brazil, 2010.

\begin{tabular}{|c|c|c|}
\hline \multirow{2}{*}{ Potential Situations in the ESF-from the IPE-APS* } & \multicolumn{2}{|c|}{ Is this an ethical problem for you? } \\
\hline & No (\%) & Yes $(\%)$ \\
\hline 01. Difficulty in setting the limits for the professional-patient relationship. & 49.4 & 50.6 \\
\hline 02. Team member prejudices against patients. & 31.5 & 68.5 \\
\hline 03. The professional treats a patient with lack of respect. & 47. 2 & 52.8 \\
\hline 04. Inadequate or wrong prescriptions. & 43.2 & 55.8 \\
\hline 05. Prescribing medication that the patient cannot purchase. & 44.7 & 55.3 \\
\hline 06. Prescribing medication that is more expensive, even where cheaper alternatives are as effective. & 47.2 & 55.8 \\
\hline 07. The patient requests procedures from his or her doctor and nurse. & 36.0 & 64.0 \\
\hline 08. Convincing a patient to maintain a treatment regime. & 37.9 & 62.1 \\
\hline 09. Withholding information on the patient's health from him or her. & 34.5 & 65.5 \\
\hline 10. Health professionals' access to private aspects of a patient's life. & 37.5 & 62.5 \\
\hline 11. It is difficult to maintain a patient's privacy when healthcare is provided at home. & 37.9 & 62.1 \\
\hline 12. It is difficult for the ACS to maintain professional secrecy. & 36.8 & 63.2 \\
\hline 13. Sharing a patient's health information with his or her family members. & 40.2 & 59.8 \\
\hline 14. Lack of commitment and engagement by certain professionals in the PSF. & 28.7 & 71.3 \\
\hline 15. The ESF teams do not collaborate. & 41.4 & 58.6 \\
\hline 16. A lack of respect between team members. & 33.3 & 66.7 \\
\hline 17. Professionals are unprepared to operate in the PSF. & 35.2 & 64.8 \\
\hline 18. It is difficult to set limits for each professional's role and responsibility. & 38.6 & 61.4 \\
\hline 19. Professionals do not object when they encounter an inadequate or wrong prescription. & 27.3 & 72.7 \\
\hline $\begin{array}{l}\text { 20. Users ask a team member to maintain secrecy regarding his/her condition with respect to the } \\
\text { remaining PSF team members. }\end{array}$ & 36.4 & 63.6 \\
\hline 21. It is difficult to preserve privacy due to problems in the USF's physical structure and routines. & 41.4 & 58.6 \\
\hline 22. Lack of support by intersector actions to discuss and solve ethical problems. & 30.7 & 69.3 \\
\hline 23. UBS administration problem solving by professionals lacks transparency. & 29.5 & 70.5 \\
\hline 24. An excessive number of families are ascribed to each team. & 41.6 & 58.4 \\
\hline $\begin{array}{l}\text { 25. Restricted patient access to the UBS because the doctors refuse to care for patients who do not } \\
\text { have an appointment. }\end{array}$ & 30.7 & 69.3 \\
\hline 26. Inappropriate referrals by PSF physicians. & 39.1 & 60.9 \\
\hline 27. Difficulties with and a lack of references for performing complementary tests. & 38.4 & 61.6 \\
\hline 28. Difficulties with laboratory test result returns and reliability. & 31.8 & 68.2 \\
\hline 29. It is difficult to limit the team's interference in patient and families lifestyles. & 37.1 & 62.9 \\
\hline 30. Doctor’s attitude toward religious values, either his/her own or the patients'. & 44.9 & 55.1 \\
\hline $\begin{array}{l}\text { 31. Underage patients ask the team for procedures and examinations without parental authorization } \\
\text { or knowledge. }\end{array}$ & 38.2 & 61.8 \\
\hline 32. Patients refuse to follow medical advice or undergo examinations. & 44.8 & 55.2 \\
\hline 33. The team discusses a patient's health condition in front of him/her without his/her participation. & 39.3 & 60.7 \\
\hline $\begin{array}{l}\text { 34. Failing to ask the family for permission before reporting the user's history in a scientific } \\
\text { publication. }\end{array}$ & 44.9 & 55.1 \\
\hline 35. USF employees question medical prescriptions. & 31.5 & 68.5 \\
\hline $\begin{array}{l}\text { 36. Medical confidentiality breach by additional members outside the team who publish case } \\
\text { histories. }\end{array}$ & 42.7 & 57.3 \\
\hline $\begin{array}{l}\text { 37. A reference specialist team for the PSF publishes a case history without previous authorization } \\
\text { by the PSF team or family. }\end{array}$ & 42.7 & 57.3 \\
\hline 38. Insufficient USF structure to perform house visits. & 31.5 & 68.5 \\
\hline 39. Insufficient conditions at the USF to provide emergency care. & 23.6 & 76.4 \\
\hline 40. Lack of support for removal services. & 27.0 & 73.0 \\
\hline
\end{tabular}

*IPE-APS adapted from Zoboli and Silva [8]. 
The 40 conditions were considered ethical problems in their professional routine by at least $50.6 \%$ of respondents. Thus, the 27 items with a positive answer from at least $60 \%$ of the respondents were maintained and analyzed through exploratory factorial analysis with the IPE-APS items' correlation matrix. These analyses were supported by the KMO $=0.84$ and Bartlett Sphericity Test $\chi^{2}(351)=1398.89 ; p<0.001$.

A principal component analysis (PCA) was performed first using the varimax rotation without fixing the number of dimensions for extraction. In total, six components with eigenvalues equal or greater than $1.0 \mathrm{t}$ were observed (11.09, 2.71, 1.59, 1.30, 1.16 and 1.04) and together accounted for $70 \%$ of the total variance. On the other hand, if the Cattell Criterion was applied, a solution with only two components was generated; however, the first criterion is more well-defined.

Because the Cattell Criterion is considered subjective, the results were validated using the most adequate solution from a parallel analysis. The same parameters from the original database were assumed (i.e., 88 valid participants and 27 items), and 1000 simulations were run. The first six random mean eigenvalues were 2.57, 2.36, $2.20,2.07,1.95$ and 1.85 . Comparing these randomly generated values to the empirical observations and previous studies indicated a structure composed of two factors because the random values exceed the effective observations at and above the third value.

Considering such results, the analyses were repeated with two dimensions for extraction; the criterion was that the item should display a $|0.50|$ minimum factorial load, and thus, items 25 and 35 were removed; both had inferior factorial loads. Factor I was composed of 14 items (16, 33, 12, 9, 19, 13, 23, 26, 14, 2, 20, 31, 11 and 10) and Factor II included 11 items (40, 39, 38, 27, 8, 17, 28, 22, 18, 7 and 29); together, they both account for $51.17 \%$ of the total variance.

Next, the internal consistency for each factor was tested; both values were satisfactory for this psychometric parameter: $\alpha_{\mathrm{I}}=0.92$ and $\alpha_{\mathrm{II}}=0.90$. Table 2 indicates factorial validity and internal consistency for the IPE-APS, which was adapted from Zoboli and Silva and contained 25 items that included the two above factors, Factor I and Factor II.

\subsection{Partial Discussion}

Science is the possibility to explain and comprehend a phenomenon as it is; it means to understand the reality from observed facts at the same time that efforts are made in the direction to explain the studied facts.

Several criteria were used to define the inventory psychometric parameters, from the least to the most robust, to establish the number of factors for extraction (Kaiser, Cattell and Parallel Analysis or Horn's Criterion) [18]. Finally, to validate the results, Horn's Criterion (parallel analysis) was used, the results from which are consistent with Cattell.

Reliability or internal consistency for such factors is satisfactory because they yielded Cronbach's Alpha values greater than 0.70 . This evidence supports the notion that the IPE-APS psychometric instruments are suitable for perceiving ethical problems in the ESF and that they can be grouped into two factors, which is described and supported below.

\subsection{Factor I and Factor II: Description and Justification}

Leopardi and Nietsche [19] assert that "[..] [t]o comprehend is to elucidate an exteriority [...] from its internal foundation, [...] in connection to the whole to which it belongs, only possible if the investigator places himself inside the event, striving to bring content and form as close as possible [...]” (pp. 65-66).

Because the inventory's constructs are common occurrences in the working routines for such professionals and are perceived as ethical problems, it is necessary to put them into context and consider several significant elements related to activities in Family Health (ESF) and outlined by Zoboli [1].

Reality is understood through external observations, which is only possible where the subject is at or around the object studied. Leopardi and Nietsche [19] assert that "[..] [t]o comprehend is to elucidate an exteriority [...], by apprehension of singularity, [...] in connection to the whole to which it belongs" (pp. 65-66).

Thus, by interpreting each item, its content type can be discerned, and a dimension can be applied to its nature; thus, their characteristics and common aspects can be determined to identify the components or factors in the inventory.

The 14 IPE-APS items labeled Factor I (2, 9, 10, 11, 12, 13, 14, 16, 19, 20, 23, 26, 31 and 33) were analyzed first; four (items 2, 16, 23 and 26) refer to prejudice and respect in relationships, each of which falls under the scope of human rights (Table 3 ). 
Table 2. The IPE-APS's factorial structure.

\begin{tabular}{|c|c|c|}
\hline Item & Factor I & Factor II \\
\hline 16 & $0.78^{*}$ & 0.12 \\
\hline 33 & $0.75^{*}$ & -0.07 \\
\hline 12 & $0.75^{*}$ & 0.21 \\
\hline 09 & $0.73^{*}$ & 0.14 \\
\hline 19 & $0.72^{*}$ & 0.25 \\
\hline 13 & $0.67^{*}$ & 0.17 \\
\hline 23 & $0.64^{*}$ & 0.40 \\
\hline 26 & $0.62^{*}$ & 0.20 \\
\hline 14 & $0.62^{*}$ & 0.26 \\
\hline 02 & $0.61^{*}$ & 0.37 \\
\hline 20 & $0.60^{*}$ & 0.44 \\
\hline 31 & $0.60^{*}$ & 0.21 \\
\hline 11 & $0.58^{*}$ & 0.23 \\
\hline 10 & $0.53^{*}$ & 0.43 \\
\hline 40 & 0.16 & $0.84^{*}$ \\
\hline 39 & 0.05 & $0.83^{*}$ \\
\hline 38 & 0.19 & $0.74^{*}$ \\
\hline 27 & 0.22 & $0.73^{*}$ \\
\hline 8 & 0.09 & $0.70^{*}$ \\
\hline 17 & 0.30 & $0.63^{*}$ \\
\hline 28 & 0.26 & $0.63^{*}$ \\
\hline 22 & 0.30 & $0.63^{*}$ \\
\hline 18 & 0.45 & $0.59^{*}$ \\
\hline 07 & 0.19 & $0.58^{*}$ \\
\hline 29 & 0.42 & $0.52^{*}$ \\
\hline Number of items & 14 & 11 \\
\hline Eigenvalue & 11.09 & 2.78 \\
\hline Total variance $\%$ & 41.10 & 10.06 \\
\hline Cronbach's alpha & 0.92 & 0.90 \\
\hline
\end{tabular}

*Item belonging to the Factor. Factor I: relationship/responsibility; Factor II: labor structure.

Table 3. Description of the IPE-APS Factor I adapted in accordance with the relationship level, content/theme and nature of the items.

\begin{tabular}{|c|c|c|c|}
\hline \multicolumn{4}{|c|}{ Factor I: relationship/responsibility } \\
\hline Relationship level & Item & Content/theme & Nature \\
\hline \multirow{2}{*}{ User } & 2 & Prejudice & Human rights \\
\hline & $9,10,11,12,13,31,33$ & Information/informed consent/confidentiality & Deontological \\
\hline \multirow{4}{*}{ Team } & 14 & Commitment to the work & Deontological \\
\hline & 16 & Respect & Human rights \\
\hline & 19 & Omission in the face of professional error & Deontological \\
\hline & 20 & Information/confidentiality & Deontological \\
\hline \multirow{2}{*}{ Management } & 23 & Prejudice/partial judgment & Human rights \\
\hline & 26 & Respect & Human rights \\
\hline
\end{tabular}


Ethics are an unavoidable dimension of humans that facilitate conscientious and responsible actions, both privately and professionally. When making a stand, deciding or judging everyday issues, professionals may manifest discrimination, stigmatization and prejudice towards social groups or individuals, which is also expresses an attitude towards a social group [20].

When managers for such services voice partial and unfair judgments, the underlying principles for justice in professional relationships are compromised, which yields unfairness and prejudice [21]. The conditions described in item 2 are similar to item 23, and thus, the same reasoning was adopted for both because it relates to prejudice/discrimination, which violates fundamental rights of humans, either for the patients, team members or persons higher in the hierarchy.

The ethical concerns referenced by items 16 and 26 are related to respect for people, which concerns conflicts and potential breaches in trust and credibility. Such conditions are depicted in the example for loud interpersonal communication. Silva [22] commented on the role of interpersonal communication in health care by stating that "[...] patients pay attention and establish relations, basically, by the way each professional manages to be coherent and complement his/her verbal and non-verbal communication [...]” (p. 73).

The remaining items $(9,10,11,12,13,14,19,20,31$ and 33) concern information/informed consent/confidentiality/commitment to work/omission before a professional error in the relationship between patients and teams (i.e., the concerns are ethical in nature), which relate to each professional's duty to patients and work colleagues.

Informed consent is the process through which a patient is duly instructed on his condition and then freely decides on the diagnostic and therapeutic procedures; it originates from professional legal and ethical duties as well as patients' legal rights and autonomy [23].

Beauchamp and Childress [24] note that a decision is morally acceptable only if it is founded on four elements: information, competence, understanding and willingness. For Altisent Trota et al. [25], the growing concern with confidentiality is characteristic of such professional activity.

Therefore, the items above concern privacy, secrecy, confidentiality and informed consent because they are related to information either as a right from the patient's perspective or as an interprofessional duty.

Notably, the discourses from subjects studied by Zoboli [1] produced the interpretation that ethical problems in a relationship context, such as for ESF, have a specific direction, which illustrates their dynamic nature. Such an interpretation is demonstrated through certain relationship levels, such as user/family, professionals, managers, and the party that is the source of the ethical problem.

Entralgo (1983) was cited by Siqueira [26] and lists three primary principles that unite professionals and patients: a) maximum technical skill, one must exercise technical expertise, prudence and common-sense when using an instrument; b) job well done, technology and science should be used for patients; and c) good intentions: when faced with moral conflicts, a professional must be guided by the patients' values and interests.

Similar to the justification for each item in Factor I, a description for the 11 items in Factor II is provided below to indicate the underlying nature (Table 4).

Items 7, 8 and 29 concern the communication/information theme and, thus, are related to the structure that supports the work at ESF. While developing arguments for the conditions analyzed herein, Zoboli [1] concluded that patients appear to have the right to autonomously question the therapeutic project. However, the key point is not to respect autonomy but to establish a practice of shared decision-making between healthcare professionals and patients [7] [8].

ESF focuses its technological-organizational changes for reorienting the healthcare model on the work process, which provides new challenges for healthcare professionals in basic care [27]. The information process

Table 4. Description of the IPE-APS Factor II adapted in accordance with the relationship level, content/theme and nature of the items*.

\begin{tabular}{ccc}
\hline & \multicolumn{2}{c|}{ Factor II: labor structure } \\
\hline Relationship level & Item & Content/theme \\
\hline User & $7,8,29$ & Communication process \\
Team & 17,18 & Technical competence \\
Management & $22,27,28,38,39,40$ & Working conditions \\
\hline
\end{tabular}

\footnotetext{
*The description of the items is shown in Table 5.
} 
is one such challenge. Considered a light but highly complex technology, communication is also a form of curriculum content, a knowledge asset and an ability that healthcare professionals should develop at the beginning of their basic training to become agents that unite and act through responsible ethics.

In medicine, the professional responsibility concept was introduced in the 18th century by two doctors, John Gregory and Thomas Percival. Professional responsibility was translated as a commitment to the following: 1) practicing deliberate medicine based on evidence and social responsibility; 2) using knowledge, skills and attitudes to protect and promote a patient's interests; and 3) maintaining and strengthening medicine as a public asset rather than a commercial alliance [28].

Items 17 and 18 concern the relationship between team members regarding technical competence, professional responsibility and continued education with special attention to the specific knowledge base that distinguishes each profession. Such ethical aspects directly affect the integrity directive stipulated by the SUS [6].

The remaining items $(22,27,28,38,39$ and 40$)$ are related to either structural or circumstantial labor conditions at the ESF management level.

\section{Study 2}

This study aimed to assess factorial congruence for the IPE-APS with 25 items, which was adapted from Zoboli and Silva.

\subsection{Method}

For convenience, this study included a non-probabilistic sample composed of 207 healthcare professionals; the 90 physicians (43.5\%) and 117 nurses (56.5\%) were selected from the 61 UBSF facilities in Goiânia (Goiás, Brazil) and were 37 years old on average; most of the healthcare professionals were female (79\%), married (58\%) and Catholic (55\%). The same procedures used in Study 1 were adopted here: approval in the CEP (72/2010) and obtaining of the TCLE.

The same procedures that were used in Study 1 were adopted here: approval was obtained from the Committee for Research Ethics in the Clinics Hospital at the UFG (72/2010), and each participant signed an informed consent form.

The univariate and multivariate quantitative statistical analyses of the PASW software package version 18 were used to organize and analyze the data from the database. Many techniques were used, including descriptive statistics, frequency as well as univariate and multivariate analyses, internal consistency or Cronbach's Alpha, principal component analysis and homogeneity.

\subsection{Results}

To test IPE-APS's factorial congruence, a novel exploratory factorial analysis was performed. First, the data matrix's factorability was analyzed with satisfactory results; $K M O=0.86$, and the Barlett's Sphericity Test $\chi^{2}$ $(300)=1831.50, p<0.001$. Therefore, the principal component analysis (PCA) was repeated using a varimax rotation with two dimensions for extraction. In this case, the first two eigenvalues were 6.86 and 3.22, which together account for $40.35 \%$ of the total variance. The factorial loads for each factor's items are described in Table 5.

As observed, the variables did not yield similar factorial loads for each factor. Therefore, it is necessary to verify whether both factorial structures are statistically similar through a factorial congruence analysis, which yielded a 0.98 factorial congruence coefficient for Factor I in both samples and 0.91 for Factor II.

\section{Final Discussion}

As expected, the hypothesis that the adapted IPE-APS would yield a high factorial congruence for both samples is supported herein. According to Jensen [29], the factorial congruence index must be greater than 0.95 to support similarity. Factor I, relationship/responsibility, produced a high congruence (above 0.95); therefore, one concludes Factor I has a high factorial similarity. Nevertheless, Factor II (labor structure) has a reasonable similarity (0.91).

This study includes certain notable limitations, particularly limitations concerning the sample, which does not necessarily represent the Brazilian, Goiás, nurse or physician populations. 
Table 5. Factorial structure of the Inventory of Ethical Problems-IPE-APS in accordance with Factors I and II and comparing nurses and physicians from Studies 1 and 2, respectively.

\begin{tabular}{|c|c|c|c|c|c|}
\hline \multirow[b]{2}{*}{ Item } & \multirow[b]{2}{*}{ Description } & \multicolumn{2}{|c|}{ Factor I } & \multicolumn{2}{|c|}{ Factor II } \\
\hline & & $\mathbf{N}_{1}$ & $\mathbf{N}_{2}$ & $\mathbf{N}_{1}$ & $\mathbf{N}_{2}$ \\
\hline 16 & Lack of respect between team members. & $0.78^{*}$ & $0.78^{*}$ & 0.12 & -0.26 \\
\hline 33 & $\begin{array}{l}\text { The team discusses the patient's health } \\
\text { condition in front of him or her without his } \\
\text { or her participation. }\end{array}$ & $0.75^{*}$ & $0.72^{*}$ & -0.07 & 0.01 \\
\hline 12 & $\begin{array}{l}\text { It is difficult for the ACS to maintain } \\
\text { professional secrecy. }\end{array}$ & $0.75^{*}$ & $0.62^{*}$ & 0.21 & 0.056 \\
\hline 09 & $\begin{array}{l}\text { Withholding information on the patient's health } \\
\text { from him or her. }\end{array}$ & $0.73^{*}$ & $0.68^{*}$ & 0.14 & -0.14 \\
\hline 19 & $\begin{array}{l}\text { Professionals do not object when they see an } \\
\text { inadequate or incorrect prescription. }\end{array}$ & $0.72^{*}$ & $0.72^{*}$ & 0.25 & 0.05 \\
\hline 13 & $\begin{array}{l}\text { Sharing information on a patient's health with his } \\
\text { or her family members. }\end{array}$ & $0.67^{*}$ & $0.66^{*}$ & 0.17 & -0.14 \\
\hline 23 & $\begin{array}{l}\text { UBS administration problem-solving problems } \\
\text { by professionals lacks transparency. }\end{array}$ & $0.64^{*}$ & $0.63^{*}$ & 0.40 & 0.21 \\
\hline 26 & Inappropriate referrals by PSF physicians. & $0.62^{*}$ & $0.48^{*}$ & 0.20 & 0.30 \\
\hline 14 & $\begin{array}{l}\text { Lack of commitment and engagement by certain } \\
\text { professionals in the PSF. }\end{array}$ & $0.62^{*}$ & $0.47^{*}$ & 0.26 & 0.43 \\
\hline 02 & Team prejudices against the patients. & $0.61^{*}$ & $0.57^{*}$ & 0.37 & 0.01 \\
\hline 20 & $\begin{array}{l}\text { Users ask a member of the team to maintain } \\
\text { secrecy regarding his or her condition from the } \\
\text { remaining PSF team members. }\end{array}$ & $0.60^{*}$ & $0.52^{*}$ & 0.44 & 0.12 \\
\hline 31 & $\begin{array}{l}\text { Underage patients ask the team for procedures } \\
\text { and examinations without parental authorization } \\
\text { or knowledge. }\end{array}$ & $0.60^{*}$ & $0.47^{*}$ & 0.21 & 0.33 \\
\hline 11 & $\begin{array}{l}\text { It is difficult to maintain patient privacy when } \\
\text { healthcare is provided at home. }\end{array}$ & $0.58^{*}$ & $0.50^{*}$ & 0.23 & 0.15 \\
\hline 10 & $\begin{array}{l}\text { Health professional access to private aspects of a } \\
\text { patient's life. }\end{array}$ & $0.53^{*}$ & $0.34^{*}$ & 0.43 & 0.11 \\
\hline 40 & Lack of support for removal services. & 0.16 & 0.01 & $0.84^{*}$ & $0.81^{*}$ \\
\hline 39 & Insufficient USF conditions for emergency care. & 0.05 & -0.08 & $0.83^{*}$ & $0.73^{*}$ \\
\hline 38 & Insufficient USF structure for house visits. & 0.19 & 0.20 & $0.74^{*}$ & $0.66^{*}$ \\
\hline 27 & $\begin{array}{l}\text { Difficulties in and a lack of references for } \\
\text { performing complementary tests. }\end{array}$ & 0.22 & 0.09 & $0.73^{*}$ & $0.76^{*}$ \\
\hline 8 & Convincing a patient to maintain treatment. & 0.09 & 0.09 & $0.70^{*}$ & $0.36^{*}$ \\
\hline 17 & Professionals are unprepared to work at the PSF. & 0.30 & 0.36 & $0.63^{*}$ & $0.51^{*}$ \\
\hline 28 & $\begin{array}{c}\text { Difficulties with laboratory test result returns and } \\
\text { reliability. }\end{array}$ & 0.26 & 0.10 & $0.63^{*}$ & $0.74^{*}$ \\
\hline 22 & $\begin{array}{l}\text { Lack of support through intersector actions to } \\
\text { discuss and solve ethical problems. }\end{array}$ & 0.30 & 0.47 & $0.63^{*}$ & $0.35^{*}$ \\
\hline 18 & $\begin{array}{l}\text { It is difficult to set limits for each professional's } \\
\text { role and responsibility. }\end{array}$ & 0.45 & 0.60 & $0.59^{*}$ & $0.28^{*}$ \\
\hline 07 & $\begin{array}{l}\text { A patient requests procedures of his or her } \\
\text { choosing from doctor and nurse. }\end{array}$ & 0.19 & -0.04 & $0.58^{*}$ & $0.41^{*}$ \\
\hline 29 & $\begin{array}{l}\text { It is difficult to limit the team's interference in } \\
\text { the families' and patients' lifestyle. }\end{array}$ & 0.42 & 0.38 & $0.52^{*}$ & $0.26^{*}$ \\
\hline
\end{tabular}

$\mathrm{N}_{1}=$ item factorial load in Study 1, and $\mathrm{N}_{2}=$ item factorial load in Study 2. * Indicates the factor to which the item belongs.

This psychometric analysis produced a high reliability (accuracy) coefficient and confirmed the inventory validity, which supports the claim that the IPE-APS is a valid instrument for detecting ethical problems in PC and that it comprises two primary components: deontological and human rights. 
Kipper and Clotet [30] write that "[...] reflection on a moral conflict arising in professional life, if performed solely under the prism of ethical references, will most likely be a myopic view into the ethical problematic contained therein [...”" (p. 40).

Ethical and bioethical education are basic necessities in training healthcare professionals. Few educational strategies focus on developing knowledge, skills and attitudes necessary to recognize ethical problems and make decisions [31]. Thus, the instrument validated herein is a tool not only for elucidating ethical problems that are perceived (or not) by healthcare professionals but also assessing their knowledge by applying the instrument before and after the teaching-learning process.

\section{Conclusions}

The IPE-APS was adapted from Zoboli \& Silva [8] and was an accurate and valid instrument for psychometric measurements of perceived ethical problems in the ESF, which was decomposed into two components after the analysis, Factors I and II. These factors comprised of relationships/responsibility and labor structure, respectively; the former was validated as a measurement instrument. The scopes for both factors include the deontological and human rights aspects for the nature of ethical problems, which may be identified by professionals through their experiences as primary healthcare providers.

Due to the curriculum reorientation directive for professions in the healthcare area and the human resources reorganization directive of the SUS, the ESF workplace is a privileged space for learning while working, and the IPE-APS may be used as a validation/measurement instrument for the teaching-learning process in bioethics and moral judgment.

\section{Funding}

There was no external funding. All resources were provided by the principal investigator.

\section{Conflicts of Interest}

There are no conflicts of interest to report.

\section{References}

[1] Zoboli, E.L.C.P. (2003) Bioética e atenção básica: Um estudo de ética descritiva com médicos do Programa Saúde da Família. Ph.D. Thesis, Universidade de São Paulo, São Paulo.

[2] Fortes, P.A.C. (1998) Ética e saúde: Questões éticas, deontológicas e legais. Autonomia e direitos do paciente. Estudo de casos. EPU, São Paulo.

[3] Bras, M., Raggio, A. and Junges, J.R. (2007) Desafios globais e participação da bioética brasileira. In: Anjos, M.F. and Siqueira, J.E., Eds., Bioética no Brasil: Tendências e perspectivas. Idéias \& Letras, Aparecida, 185-211.

[4] Pessini, L., Barchifontaine, C.P. and Prado, M.M. (2007) Bioética no Brasil: Produção científica e perspectivas. In: Anjos, M.F. and Siqueira, J.E., Eds., Bioética no Brasil: Tendências e perspectivas. Idéias \& Letras, Aparecida, 214-235.

[5] Siqueira, J.E., Porto, D. and Fortes, P.A.C. (2007) Linhas temáticas da Bioética no Brasil. In: Anjos, M.F. and Siqueira, J.E., Eds., Bioética no Brasil: Tendências e perspectivas. Idéias \& Letras, Aparecida, 161-184.

[6] Ministério da Saúde (1997) Secretaria de Assistência à Saúde. Saúde da família: Uma estratégia para reorientação do modelo assistencial. Ministério da Saúde, Brasília. http://bvsms.saude.gov.br/bvs/publicacoes/cd09_16.pdf

[7] Zoboli, E.L.C.P. (2007) Enfermeiros e usuários do Programa Saúde da Família: Contribuições da bioética para reorientar esta relação. Acta Paulista de Enfermagem, 20, 316-320.

http://dx.doi.org/10.1590/S0103-21002007000300012

[8] Silva, L.T. (2008) Construção e validação de um instrumento para avaliação de ocorrência de problemas éticos na atenção básica. Dissertation (Master in Nursing), Universidade de São Paulo, São Paulo.

[9] Zoboli, E.L.C.P. (2010) Relación clínica y problemas éticos en atención primaria, São Paulo, Brasil. Aten Primaria, 42, 406-412. http://dx.doi.org/10.1016/j.aprim.2010.01.018

[10] Junges, J.R., Schaefer, R., Della Nora, C.R., Basso, M., Silocchi, C., Souza, M.C., et al. (2012) Hermenêutica dos problemas éticos percebidos por profissionais da atenção primária. Revista Bioética (Impr), 20, 937-944.

[11] Laabs, C.A. (2005) Moral Problems and Distress among Nurse Practitioners in Primary Care. Journal of the American 
Academy of Nurse Practitioners, 17, 76-84. http://dx.doi.org/10.1111/j.1041-2972.2005.00014.x

[12] Redman, B.K. (2006) Review of Measurement Instruments in Clinical and Research Ethics, 1999-2003. Journal of Medical Ethics, 32, 153-156. http://dx.doi.org/10.1136/jme.2005.012567

[13] Falcó-Pegueroles, A., Lluch-Canut, T. and Guárdia-Olmos, J. (2013) Development Process and Initial Validation of the Ethical Conflict in Nursing Questionnaire-Critical Care Version. BMC Medical Ethics, 14, 22. http://dx.doi.org/10.1186/1472-6939-14-22

[14] Sánchez García, Z., Marrero Rodríguez, J.N., Becerra Pena, O. and Alvarado Peruyero, J.C. (2003) Los principios bioéticos en la atención primaria de salud: Apuntes para una reflexión. Revista Cubana de Medicina General Integral [Electronic Magazine], 19.

http://scielo.sld.cu/scielo.php?script=sci_arttext\&pid=S0864-21252003000500012\&lng=es\&nrm=iso

[15] Zoboli, E.L.C.P. and Fortes, P.A.C. (2004) Bioética e atenção básica: Um perfil dos problemas éticos vividos por enfermeiros e médicos do Programa Saúde da Família, São Paulo, Brasil. Cadernos de Saúde Pública, 20, 1690-1699. http://dx.doi.org/10.1590/S0102-311X2004000600028

[16] Silva, L.T., Zoboli, E.L.C.P. and Borges, A.L.V. (2006) Bioética e atenção básica: Um estudo exploratório dos problemas vividos por enfermeiros e médicos no PSF. Cogitare Enfermagem, 11, 133-142.

[17] Lima, A.C., Morales, D.A.M., Zoboli, E.L.C.P. and Sartório, N.A.S. (2009) Problemas éticos na atenção básica: A visão de enfermeiros e médicos. Cogitare Enfermagem, 14, 294-303.

[18] Pereira, J.C.R. (2001) Análise de dados qualitativos: Estratégias metodológicas para as Ciências da Saúde, Humanas e Sociais. Ed Universidade de São Paulo, São Paulo.

[19] Leopardi, M.T. and Nietsche, E.A. (2001) Método científico. In: Leopardi, M.T., Beck, C.L.C., Nietsche, E.A. and Gonzales, R.M.B., Eds., Metodologia da pesquisa na saúde, Pallotti, Santa Maria, 109-125.

[20] Vasconcelos, T.C., Gouveia, V.V., Souza Filho, M.L., Sousa, D.M.F. and Jesus, G.R. (2004) Preconceito e intenção em manter contato social: Uma evidência acerca dos valores humanos. Psico-USF, 9, 147-154.

[21] Ros, M. (2006) Valores, atitudes e comportamento: Uma nova visita a um tema clássico. In: Ros, M. and Gouveia, V.V., Eds., Psicologia social dos valores humanos, Ed. Senac, São Paulo, 87-114.

[22] Silva Maria, J.P.S. (2002) O papel da comunicação na humanização da atenção à saúde. Revista Bioética, 10, 73-88.

[23] Munhoz, D.R. and Fortes, P.A.C. (1998) O princípio da autonomia e o consentimento livre e esclarecido. In: Costa, S.I.F., Garrafa, V. and Oselka, G., Eds., Iniciação à bioética, Conselho Federal de Medicina, Brasília, 53-70.

[24] Beauchamp, T. and Childress, J.F. (2002) Princípios de ética biomédica. Ed. Loyola, São Paulo.

[25] Altisent Trota, R., Delgado Marroquín, M.T., Garrijo, L.J., Espíldora, M.N.M., Moral, R.R., et al. (1994) Sobre bioética y medicina de familia. Sociedad Española de Medicina de Familia y Comunitária (semFYC), Barcelona. http://www.samfyc.es/pdf/GdTBio/201039.pdf?iframe=true\&width=80\%\&height $=80 \%$

[26] Siqueira, J.E. (2008) A arte de cuida. In: Siqueira, J.E., Zoboli, E.L.C.P. and Kipper, D., Eds., Bioética clínica, Gaia, São Paulo, 36-62.

[27] Silva, A.C.B. and Athayde, M. (2008) O Programa de Saúde da Família sob o ponto de vista da atividade: Uma análise das relações entre os processos de trabalho, saúde e subjetivação. Revista Brasileira de Saúde Ocupacional, 33, 23-35. http://dx.doi.org/10.1590/S0303-76572008000100004

[28] McCullough, L. (2013) Professional Responsibility to and for Patients and the Ethics of Health Policy. American Journal of Bioethics, 13, 16-28. http://dx.doi.org/10.1080/15265161.2013.804339

[29] Jensen, A. (1998) The g Factor. Praeger, London.

[30] Kipper, D.J. and Clotet, J. (1998) Princípios da beneficência e não-maleficência. In: Costa, S.I.F. and Garrafa, V., Eds., Iniciação à Bioética, Conselho Federal de Medicina, Brasília, 37-70.

[31] Guedert, J.M. and Grosseman, S. (2011) Abordagem dos problemas éticos em pediatria: Sugestões advindas da prática. Revista Brasileira de Educação Médica, Rio de Janeiro, 35, 359-368. http://dx.doi.org/10.1590/S0100-55022011000300009 
Scientific Research Publishing (SCIRP) is one of the largest Open Access journal publishers. It is currently publishing more than 200 open access, online, peer-reviewed journals covering a wide range of academic disciplines. SCIRP serves the worldwide academic communities and contributes to the progress and application of science with its publication.

Other selected journals from SCIRP are listed as below. Submit your manuscript to us via either submit@scirp.org or Online Submission Portal.
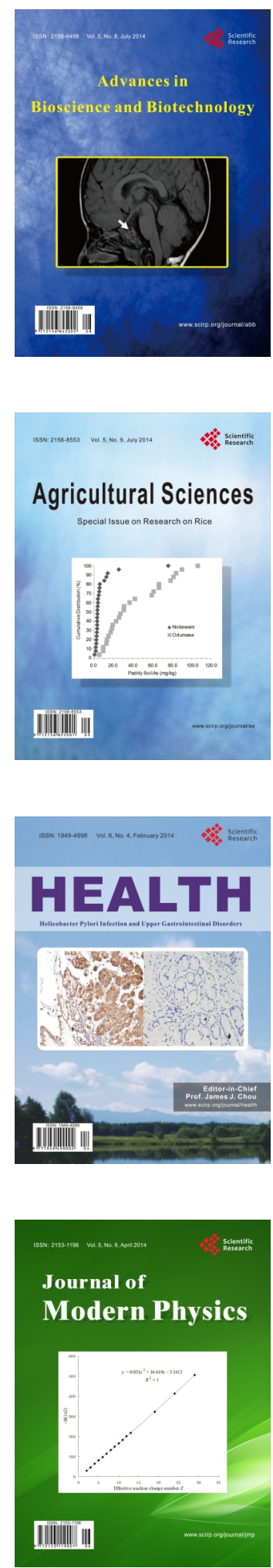
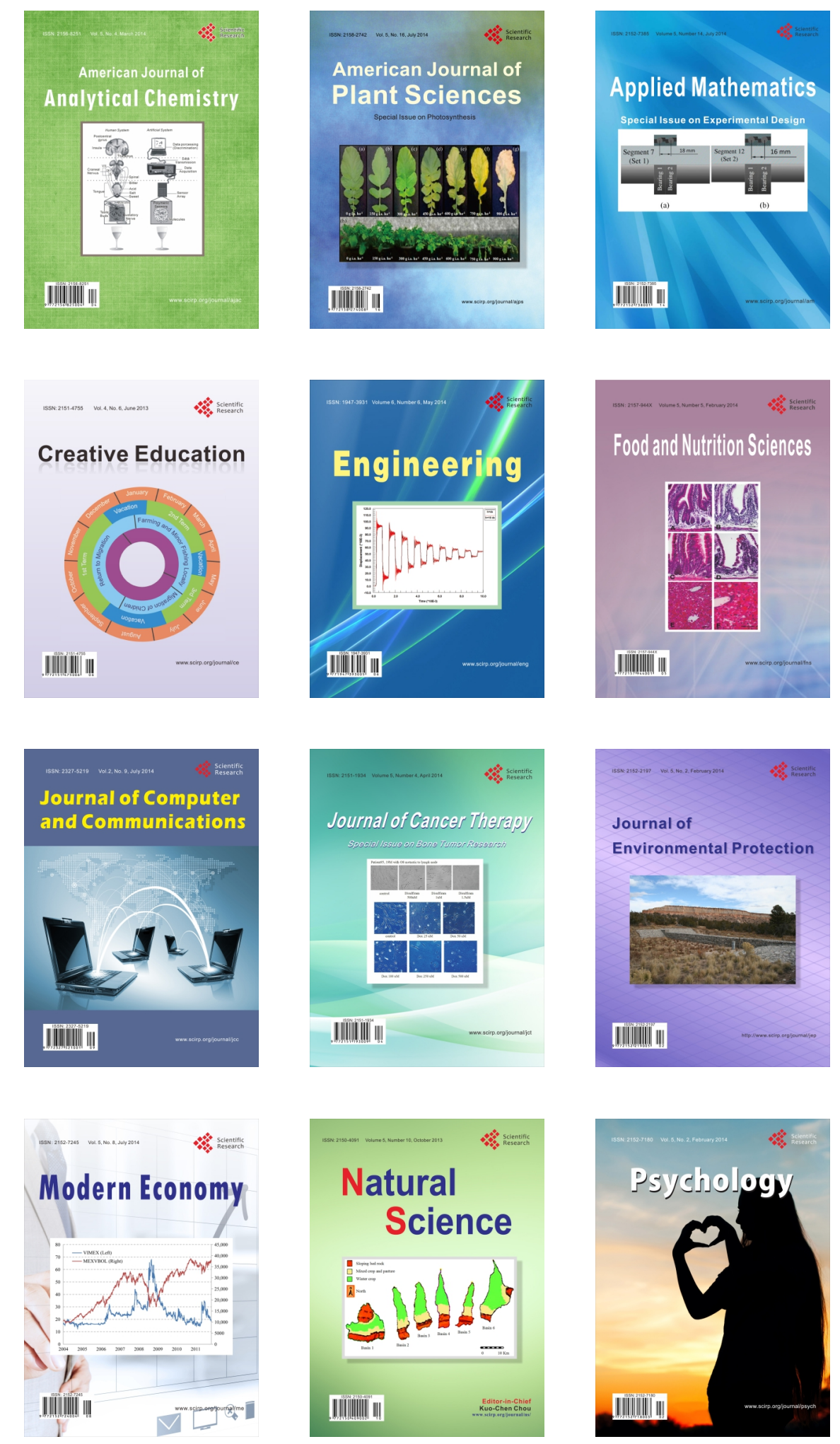